\title{
Lean Healthcare in the institutional, professional, and patient perspective: an integrative review
}

\author{
Lean Healthcare na perspectiva institucional, profissional \\ e do paciente: uma revisão integrativa \\ Lean Healthcare en la perspectiva institucional, profesional \\ y del paciente: una revisión integrativa
}

\author{
Hellen Maria de Lima Graf Fernandes ${ }^{a}$ \\ Mariana Véo Nery de Jesus ${ }^{a}$ \\ Dirceu da Silva ${ }^{b}$ \\ Edinêis de Brito Guirardello ${ }^{a}$
}

\section{How to cite this article:} Fernandes HMLG, Jesus MVN, Silva D, Guirardello EB. Lean Healthcare in the institutional, professional, and patient perspective: an integrative review. Rev Gaúcha Enferm. 2020;41:e20190340 doi: https://doi.org/10.1590/19831447.2020.20190340
Universidade Estadual de Campinas (UNICAMP) Faculdade de Enfermagem, Programa de Pós Graduação em Enfermagem. Campinas, São Paulo, Brasil

${ }^{b}$ Universidade Estadual de Campinas (UNICAMP) Faculdade de Educação. Campinas, São Paulo, Brasil

\section{ABSTRACT}

Objective: To analyze the scientific evidences in the literature about the evaluation of Lean Healthcare after its implementation. Method: An integrative review conducted in the CINAHL, Scopus, WOS, and Embase databases, and in the PubMed portal, resulting in 18 articles published in English, Spanish and Portuguese, from 2008 to 2019

Results: The findings were categorized into results for the institution, professional, and patient. The predominant category was institutional, with cost analysis and increased productivity, followed by the professional, with job satisfaction and leadership, and finally the patient, with satisfaction, attitudes, and behaviors.

Conclusion: This study reinforces the need to establish, for management, a systematic method of monitoring the results achieved in the Lean Healthcare implementation phase. Since the value in this method is defined by the patient, further research in this aspect may lead to new evidence.

Keywords: Total quality management. Quality improvement. Health management.

\section{RESUMO}

Objetivo: Analisar as evidências científicas na literatura sobre avaliação do Lean Healthcare após sua implantação.

Método: Revisão integrativa realizada nas bases de dados CINAHL, Scopus, WOS, Embase e no portal PubMed, resultando 18 artigos publicados nos idiomas inglês, espanhol e português, no período de 2008 a 2019.

Resultados: 0 s achados foram categorizados em resultados para a instituição, profissional e paciente. A categoria predominante foi a institucional, com análise de custo e aumento da produtividade, seguida do profissional, com satisfação no emprego e liderança, e por fim o paciente, com satisfação, atitudes e comportamentos.

Conclusão: Este estudo reforça a necessidade em estabelecer, para a gestão, um método sistemático de acompanhamento dos resultados alcançados na fase de implantação do Lean Healthcare. Sendo o valor nesse método definido pelo paciente, novas pesquisas nesse aspecto poderão levar a novas evidências.

Palavras-chave: Gestão da qualidade total. Melhoria de qualidade. Gestão em saúde.

\section{RESUMEN}

Objetivo: Analizar las evidencias científicas en la literatura sobre la evaluación de Lean Healthcare después de su implementación.

Método: Revisión integradora realizada en las bases de datos CINAHL, Scopus, WOS, Embase y en el portal PubMed, con la obtención de 18 artículos publicados en inglés, español y portugués, de 2008 a 2019.

Resultados: Los hallazgos se clasificaron en resultados para las categorías institucional, profesional y paciente. La categoría predominante fue la institucional, con análisis de costos y mayor productividad, seguida por la profesional, con satisfacción laboral y liderazgo y, finalmente, la del paciente, con satisfacción, actitudes y comportamientos.

Conclusión: Este estudio refuerza la necesidad de establecer, para la administración, un método sistemático de monitoreo de los resultados logrados en la fase de implementación de Lean Healthcare. Dado que el valor en este método es definido por el paciente, la investigación adicional en este aspecto puede conducir a nuevas pruebas.

Palabras clave: Gestión de la calidad total. Mejoramiento de la calidad. Gestión en salud. 


\section{IINTRODUCTION}

Lean is a management philosophy derived from the Toyota System, widely applied in the industry and adapted to the health area in order to reduce costs and optimize resources through a process review to generate value for the patient ${ }^{(1-2)}$.

It is an integrated system of principles, practices, tools, and techniques focused on reducing waste, synchronizing workflows and managing its variability, which, when applied in the health area, is called Lean Healthcare ${ }^{(3)}$.

This methodology is not simply a manufacturing technique for reducing waste and costs, but a philosophy that is applied in any type of organization and depends on several factors to achieve satisfactory results. Health institutions are complex and with many processes that can be improved with the use of the tools proposed by Lean ${ }^{(4)}$.

Lean Healthcare is based on a five-stage process that, after adapting the principles of Lean ${ }^{(5)}$, were presented as follows: i) defining the value of the clients to meet their needs, such as diagnostic tests and indicated therapy; ii) mapping the value, which includes defining activities from the beginning to the end of the process stages; iii) reviewing the value stream to identify waste and solve it, that is, adapting and being efficient in health care iv) pulling, defined by the ability to signal the pace of the activities for the following stages, with a view to avoiding stocks and; $v$ ) the quest for perfection, a stage that must drive the continuous improvement of Lean Healthcare with the care provided in a timely manner and with quality ${ }^{(2,6)}$.

Several studies present the process of implementing Lean in different health settings: pharmacy ${ }^{(7)}$, gynecology and obstetrics service ${ }^{(8)}$, oncology ${ }^{(9)}$, radiotherapy ${ }^{(10)}$, operating rooms ${ }^{(11)}$, and enteral diet therapy in the medical surgical unit ${ }^{(12)}$.

It is worth highlighting some studies that used the principles of Lean and that brought benefits such as: improved workflow ${ }^{(7-8,12)}$; reduction of waste ${ }^{(10,12)}$; and increased patient and professional satisfaction ${ }^{(10,13)}$; in addition to improving the operating and financial results of the institutions ${ }^{(10,12)}$.

However, longitudinal studies to monitor the results of its long-term implementation and its consequences for institutions, teams and patients are still scarce. Systematic reviews point to the need to improve the quality of evidence, in addition to the use of clear terminology for Lean Healthcare, transforming the language of manufacturing into one centered on health care ${ }^{(3,14-16)}$.

Given the above and the relevance of the Lean philosophy for management in health institutions, and because it is a relatively new subject, with the first publications appearing in 2002, the objective of the study was to analyze the scientific evidence in the literature on the evaluation of Lean Healthcare after its implementation.

\section{METHOD}

An integrative review study based on the recommendations of the Preferred Reporting Items for Systematic Reviews and Meta-Analyses - PRISMA ${ }^{(17)}$ guidelines and included in the identification stages of the problem; literature search; evaluation and selection; analysis and interpretation of data ${ }^{(18)}$. Therefore, the following was established as the research question: What were the results after the implementation of Lean Healthcare in health institutions?

The inclusion criteria considered the studies published in the last ten years (2008-2019) that address the proposed theme, and the availability of the entire text for the reader, in addition to them being written in English, Portuguese or Spanish. Editorials, letters to the editor, review studies, theses, dissertations, and studies that did not answer the research question or that described only the implementation stage of Lean were excluded.

The search for studies was carried out between July and September 2019, in the Cumulative Index to Nursing and Allied Health Literature (CINAHL), Scopus, Web of Science (WOS), and Embase databases, as well as the US National Library of Medicine (PubMed) portal.

Medical Subject Headings (MeSH) were selected to search in the electronic databases. Thus, the following MeSH terms were used in the search strategy: "Total Quality Management", "Quality Improvement" and the keyword "Lean healthcare", defined by the authors after previous reading of the theme. The Boolean operators AND and OR were used in the crossing of the MeSH term and the keyword to expand the search for scientific evidence.

The initial search in each database, using the intersections of the search terms, according to each controlled vocabulary (MesH, EMTREE, and CINAHL titles) and keyword, resulted in 126 documents, which went through new stages of selection, represented in the flowchart in Figure 1. The search and selection of studies were carried out simultaneously by two researchers and, in situations of divergence, consensus was sought with the participation of an auxiliary researcher.

To classify the level of evidence, seven levels were considered: level I - evidence from a systematic review or meta-analysis of all the relevant and randomized controlled trials or from guidelines based on systematic reviews of randomized controlled trials; level II - evidence obtained from at least 


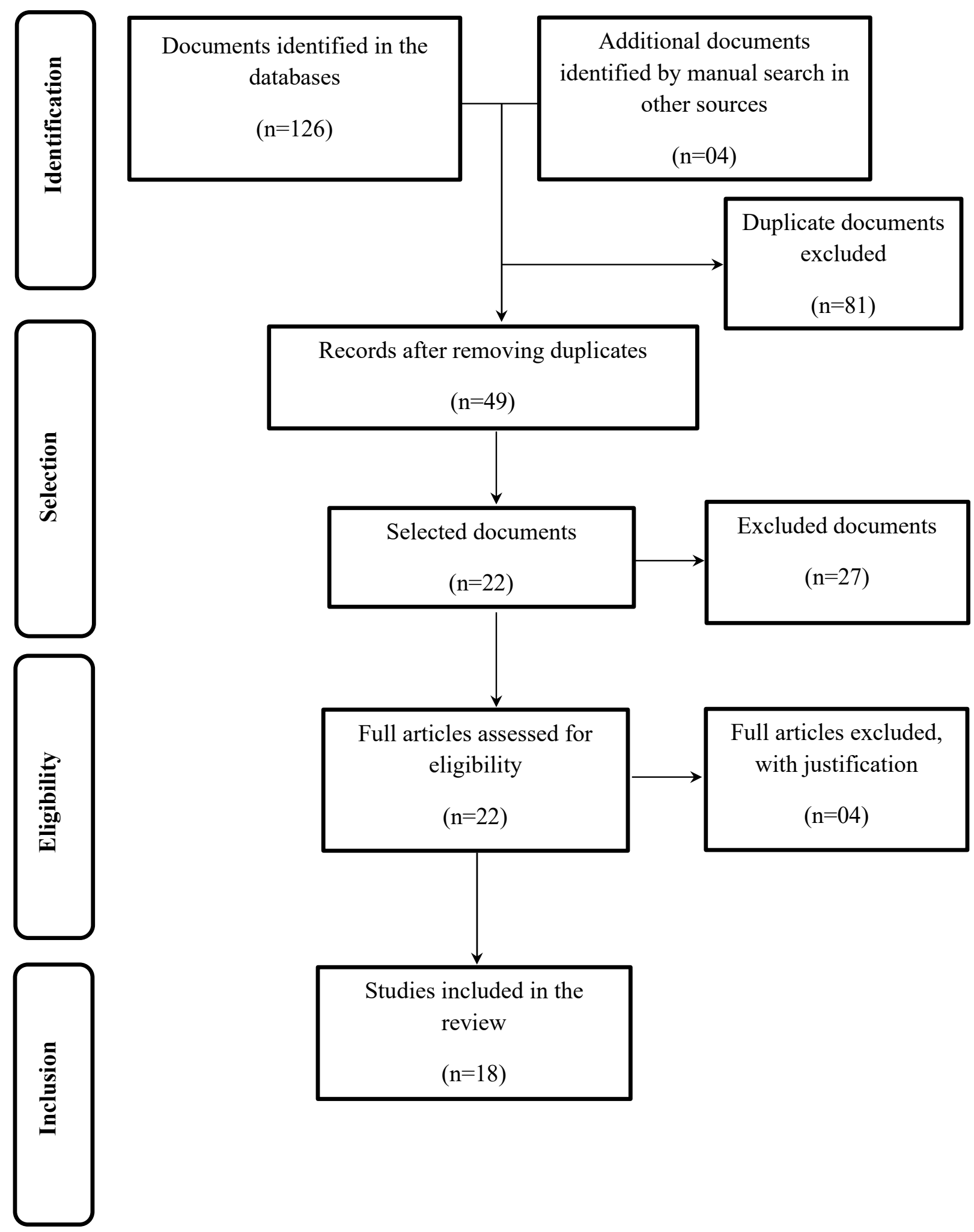

Figure 1 - Flowchart prepared in accordance with the PRISMA recommendations for the process of identification, selection, and inclusion of articles. Campinas, SP, Brazil, 2019 Source: The authors. 
one randomized, controlled and well-designed clinical trial; level III - evidence of a well-designed and controlled study, without randomization; level IV - evidence from cohort or case-control studies; level V - evidence of a systematic review of descriptive and qualitative studies; level VI - evidence derived from a single descriptive or qualitative study; and level VII - evidence from the opinion of authorities and/or experts/expert committee reports ${ }^{(19)}$.

\section{Q RESULTS}

A total of 126 articles were identified in the databases: 20 in CINAHL, 26 in Embase, 26 in PubMed, 37 in Scopus, and 17 in WOS, in addition to four articles included manually, searched from the verification of the reference lists, totaling 130 documents.

The reference manager (EndNote) was used to organize the search results, remove duplications, and assist in the selection. A total of 81 repeated studies were excluded, resulting in 49 documents. Subsequently, the titles and abstracts were read, excluding those that did not meet the criteria. Then, after a thorough and detailed reading, another four studies were excluded, as they did not answer the research question, resulting in a final sample of 18 articles.

For the analysis of the selected articles, a spreadsheet was built by the authors in order to target the evaluation and validation of the included studies, containing the following information: First author, year, country, objective, type of study, place of implementation, sample, perspective of analysis of results, level of evidence and main findings (Chart 1).

The final sample presented $88.9 \%$ of international productions and $11.1 \%$ of national ones. As for the focus, $27.7 \%$ of the articles have a qualitative approach, 50.0\% quantitative, and $22.3 \%$ mixed. Regarding the design, we found variety in the types of studies presented, highlighting three studies that used more robust designs: Iongitudinal, experimental, and cohort. Thus, regarding the levels of evidence, $77.7 \%$ were level $\mathrm{VI}$ and $16.6 \%$, level IV ${ }^{(19)}$. One study could not be classified regarding the level of evidence, as it did not specify the type of study carried out.

For the analysis of the findings, they were categorized into results from the perspective of the institution, the professional, and the patient.

\section{DISCUSSION}

The eighteen articles that met the inclusion criteria were published in English between 2014 and 2019, with the majority being in the last three years (55.5\%). As for the location, they were carried out in European (38.9\%), American (33.3\%), Asian (16.7\%) and African (11.1\%) countries. It is worth mentioning that the two articles from Brazil were published by authors from the state of São Paulo.

The findings showed diversity regarding the contexts in which Lean was implemented. The hospital area was predominant, accounting for $50 \%$ of the studies, followed by primary care and by support and diagnostic health services, with $12.3 \%$ and $16.6 \%$, respectively. Two studies ${ }^{(29,34)}(11.1 \%)$ carried out their analyses in two concomitant scenarios: assistance, and support and diagnosis services.

The results are presented below, according to the proposed grouping, in the perspective of evaluation after the implementation of Lean Healthcare in the categories: institutional, professional and patients.

From the institutional perspective, the studies brought results related to the work environment ${ }^{(32)}$; waste reduction ${ }^{(22,26,29)}$; cost analysis ${ }^{(22,26,28,33)}$; increase in productivity $^{(11,22,24,26)}$; financial return ${ }^{(22,24)}$; response time ${ }^{(24,26)}$, permanence ${ }^{(28,30)}$ and waiting time of the patient ${ }^{(30)}$; improvement in the performance of institutional indicators ${ }^{(23,36)}$; increase in the installed capacity of the services ${ }^{(24)}$; improvement in quality of care(26,32); optimization of the physical structure ${ }^{(11)}$; turnover time ${ }^{(11)}$, and impacts on transformational leadership ${ }^{(27)}$.

In addition, a study conducted in Brazil compared the application of the traditional model of Total Quality with a theoretical approach of Lean Healthcare cases and a practical situation of this philosophy. It was concluded that Lean was better systematically appropriate, considering that it kept the focus on the patient, through the use of interaction instruments. On the other hand, the application of Total Quality did not promote team participation and partially shifted the responsibility from the professionals to bureaucratic tasks, causing a loss of focus ${ }^{(29)}$. It is highlighted that Lean proposes participatory management with greater involvement of the workers in decision-making processes, dividing responsibility and sharing power (24).

It is worth highlighting the study ${ }^{(20)}$ that proposed a new perspective of analysis, evaluating the maturity of institutional Lean. High maturity was considered when all the principles were adopted and by all the employees, their evaluation being relevant, since it contributes to the analysis and sustainability of the results achieved with the method ${ }^{(37-38)}$. Therefore, when evaluating in the context of primary care, the author obtained a variation in maturity between and within the health units. The greatest maturity was found for the "adhering to routines" item and the lowest for the 


\begin{tabular}{|c|c|c|c|c|c|}
\hline $\begin{array}{l}1^{\text {st }} \text { Author } \\
\text { Year } \\
\text { Place }\end{array}$ & Objective & $\begin{array}{l}\text { Type of study } \\
\text { Sample }\end{array}$ & Perspective & Main findings & $\begin{array}{l}\text { Level of } \\
\text { Evidence }\end{array}$ \\
\hline $\begin{array}{l}\text { Kaltenbrunner(20) } \\
2019 \\
\text { Sweden }\end{array}$ & $\begin{array}{l}\text { To describe Lean maturity in } \\
\text { primary care and to determine the } \\
\text { extent to which Lean maturity is } \\
\text { associated with quality of care. }\end{array}$ & $\begin{array}{l}\text { Descriptive, correlational, } \\
\text { and mixed methods } \\
n=298 \text { employees }\end{array}$ & $\begin{array}{l}\text { Institutional } \\
\text { Professional }\end{array}$ & $\begin{array}{l}\text { Lean maturity varied between and within } \\
\text { units. The highest level of maturity was } \\
\text { found for "adhering to routines" and the } \\
\text { lowest for "having a change agent in the } \\
\text { unit". Maturity was positively associated } \\
\text { with satisfaction with care and adherence } \\
\text { to the national guidelines to improve the } \\
\text { quality of health care }\end{array}$ & $\mathrm{VI}$ \\
\hline $\begin{array}{l}\text { Fournier(21) } \\
2018 \\
\text { Canada }\end{array}$ & $\begin{array}{l}\text { To study the factors that influence } \\
\text { the involvement of physicians in } \\
\text { Lean change initiatives in public } \\
\text { health organizations }\end{array}$ & $\begin{array}{l}\text { Inductive method } \\
\mathrm{n}=18 \text { physicians }\end{array}$ & Professional & $\begin{array}{l}\text { Younger, less experienced physicians were } \\
\text { more likely to commit to the Lean initiative, } \\
\text { in addition to the previous level of training } \\
\text { and positive experience with the method }\end{array}$ & VI \\
\hline $\begin{array}{l}\text { Gupta }^{(22)} \\
2018 \\
\text { India }\end{array}$ & $\begin{array}{l}\text { To discuss the implementation of } \\
\text { the Lean methodology to reduce } \\
\text { the response time of a clinical } \\
\text { laboratory in a specialized hospital }\end{array}$ & $\begin{array}{l}\text { Experimental method } \\
n=215 \text { samples }\end{array}$ & Institutional & $\begin{array}{l}\text { The results showed waste elimination, cost } \\
\text { reduction, higher productivity and return } \\
\text { on investments after the implementation } \\
\text { of Lean }\end{array}$ & IV \\
\hline $\begin{array}{l}\text { Boronat }^{(23)} \\
2018 \\
\text { Spain }\end{array}$ & $\begin{array}{l}\text { To describe the application of the } \\
\text { Lean methodology as a method to } \\
\text { continuously improve the efficiency } \\
\text { of an urology department in a } \\
\text { tertiary-level hospital }\end{array}$ & $\begin{array}{l}\text { Cross-sectional study } \\
\text { Not specified. }\end{array}$ & $\begin{array}{l}\text { Institutional } \\
\text { Professional }\end{array}$ & $\begin{array}{l}\text { The Lean methodology can be } \\
\text { effectively applied to improve efficiency, } \\
\text { obtaining significant and continuous } \\
\text { improvements in all its indicators, as well as } \\
\text { professional satisfaction. }\end{array}$ & $\mathrm{VI}$ \\
\hline $\begin{array}{l}\text { Costa }^{(24)} \\
2017 \\
\text { Brazil }\end{array}$ & $\begin{array}{l}\text { To assess how five sectors of } \\
\text { two Brazilian hospitals have } \\
\text { implemented Lean health concepts } \\
\text { in their operations }\end{array}$ & $\begin{array}{l}\text { Case study } \\
\mathrm{n}=\text { Sectors } \mathrm{A} \text { (CME } \\
\text { and pharmacy) and B } \\
\text { (chemotherapy, operating } \\
\text { room, and radiotherapy) }\end{array}$ & Institutional & $\begin{array}{l}\text { The results evidenced the improvement } \\
\text { of the financial aspects, in the reduction } \\
\text { of the delivery time, in the increase of the } \\
\text { capacity, and in productivity }\end{array}$ & $\mathrm{VI}$ \\
\hline
\end{tabular}

Chart 1 - Characterization of the studies in relation to the 1st author, year, country, objective, type of study, place of implementation, sample, perspective of analysis of the implementation, level of evidence, and main findings. Campinas, SP, Brazil, 2019. 


\begin{tabular}{|c|c|c|c|c|c|}
\hline $\begin{array}{l}1^{\text {st }} \text { Author } \\
\text { Year } \\
\text { Place }\end{array}$ & Objective & $\begin{array}{l}\text { Type of study } \\
\text { Sample }\end{array}$ & Perspective & Main findings & $\begin{array}{l}\text { Level of } \\
\text { Evidence }\end{array}$ \\
\hline $\begin{array}{l}\text { Poksinska }^{(25)} \\
2017 \\
\text { Sweden }\end{array}$ & $\begin{array}{l}\text { To investigate how primary care } \\
\text { centers define and improve patient } \\
\text { value and satisfaction using Lean }\end{array}$ & $\begin{array}{l}\text { Mixed method } \\
\text { Case Study/Survey } \\
\text { Qualitative phase: } \\
\mathrm{n}=15 \text { professionals } \\
\text { Quantitative phase } \\
23 \text { control groups and } 23 \\
\text { intervention groups }\end{array}$ & Patient & $\begin{array}{l}\text { Did not show significant results in } \\
\text { patient satisfaction }\end{array}$ & $\mathrm{VI}$ \\
\hline $\begin{array}{l}\text { Mutingi(26) } \\
2017 \\
\text { South Africa }\end{array}$ & $\begin{array}{l}\text { To assess the impact of adopting } \\
\text { Lean tools in the medical laboratory } \\
\text { services in Namibia }\end{array}$ & $\begin{array}{l}\text { Descriptive, cross- } \\
\text { sectional study and } \\
\text { mixed method } \\
n=72 \text { laboratories }\end{array}$ & $\begin{array}{l}\text { Institutional } \\
\text { Professional } \\
\text { Patient }\end{array}$ & $\begin{array}{l}\text { The application of Lean tools had a positive } \\
\text { impact, and management support plays } \\
\text { an important role in success. The quality } \\
\text { improvement had an impact in more than } \\
85 \% \text { of the laboratories. Lean tools have } \\
\text { improved quality operational performance, } \\
\text { reduced response times, improved } \\
\text { employee motivation, and reduced costs }\end{array}$ & $\mathrm{VI}$ \\
\hline $\begin{array}{l}\text { Hassanain } \\
2017 \\
\text { Saudi } \\
\text { Arabia }\end{array}$ & $\begin{array}{l}\text { To assess whether an intervention } \\
\text { using Lean principles in hospitals } \\
\text { across Saudi Arabia would impact } \\
\text { on the performance metrics in the } \\
\text { operating room: use of the room, } \\
\text { medical file opening for the first } \\
\text { cases, turnover times, overrun cases, } \\
\text { and weekly procedure volumes }\end{array}$ & $\begin{array}{l}\text { Quasi-experimental } \\
\text { design } \\
n=12 \text { Hospitals }\end{array}$ & Institutional & $\begin{array}{l}\text { Statistically significant improvements in } \\
\text { the beginning of the first surgery time, } \\
\text { room turnover times, and percentage of } \\
\text { overrun cases. No significant statistical } \\
\text { difference was detected in the use of } \\
\text { the operating room or mean volumes of } \\
\text { weekly procedures }\end{array}$ & $\mathrm{VI}$ \\
\hline
\end{tabular}

Chart 1 - Cont. 


\begin{tabular}{|c|c|c|c|c|c|}
\hline $\begin{array}{l}1^{\text {st }} \text { Author } \\
\text { Year } \\
\text { Place }\end{array}$ & Objective & $\begin{array}{l}\text { Type of study } \\
\text { Sample }\end{array}$ & Perspective & Main findings & $\begin{array}{l}\text { Level of } \\
\text { Evidence }\end{array}$ \\
\hline $\begin{array}{l}\text { Van Rossum } \\
2016 \\
\text { Netherlands }\end{array}$ & $\begin{array}{l}\text { To enhance scientific knowledge } \\
\text { about factors that close the } \\
\text { implementation gap and make } \\
\text { the transition from the "Lean } \\
\text { toolbox" to a real transformation } \\
\text { into Lean Healthcare in the } \\
\text { operating room }\end{array}$ & $\begin{array}{l}\text { Cross-sectional study } \\
\text { n=103 participants }\end{array}$ & $\begin{array}{l}\text { Institutional } \\
\text { Professional }\end{array}$ & $\begin{array}{l}\text { The correlation and regression analyses } \\
\text { showed positive relationships between } \\
\text { transformational leadership and team } \\
\text { leadership styles and the implementation } \\
\text { of Lean. The results also indicated a strong } \\
\text { relationship between workforce flexibility } \\
\text { and the implementation of Lean Healthcare }\end{array}$ & $\mathrm{VI}$ \\
\hline $\begin{array}{c}\text { Trzeciak }^{(28)} \\
2016 \\
\text { USA }\end{array}$ & $\begin{array}{l}\text { To test the hypothesis that a } \\
\text { Lean Six Sigma approach to process } \\
\text { improvement could reduce the } \\
\text { length of hospital stay and the } \\
\text { costs associated with caring } \\
\text { for patients with prolonged } \\
\text { mechanical ventilation }\end{array}$ & $\begin{array}{l}\text { Cohort study } \\
\mathrm{n}=259 \text { patients } \\
\text { (31 pre-intervention; } \\
128 \text { post-intervention) }\end{array}$ & Institutional & $\begin{array}{l}\text { The intervention resulted in a } \\
24 \% \text { reduction in the hospital } \\
\text { stay ( } 29 \text { days/ } 22 \text { days, } p<0.001 \text { ) and in a } \\
27 \% \text { reduction in the direct hospital cost } \\
\text { per case (US } \$ 66,335 / U S \$ 48,370, p<0.001 \text { ) }\end{array}$ & IV \\
\hline $\begin{array}{l}\text { Eiro(29) } \\
2015 \\
\text { Brazil }\end{array}$ & $\begin{array}{l}\text { To compare the application of } \\
\text { the Total Quality models used in } \\
\text { health service processes, the cases } \\
\text { of Lean Healthcare in the literature } \\
\text { and of another institution that has } \\
\text { already applied this model }\end{array}$ & $\begin{array}{l}\text { Qualitative and } \\
\text { descriptive, case study } \\
\text { n=Two health institutions: } \\
\text { A (private diagnostic } \\
\text { medicine company); } B \\
\text { (private cancer hospital) }\end{array}$ & Institutional & $\begin{array}{l}\text { The Lean model was better systematically } \\
\text { appropriated by the people who } \\
\text { work and generate flow leading to } \\
\text { greater adherence. }\end{array}$ & $\mathrm{Vl}$ \\
\hline $\begin{array}{l}\text { Kane }^{(30)} \\
2015 \\
\text { USA }\end{array}$ & Not specified & $\begin{array}{l}\text { Not specified } \\
\text { Not specified }\end{array}$ & $\begin{array}{l}\text { Institutional } \\
\text { Patient }\end{array}$ & $\begin{array}{l}\text { The implementation of Lean in the } \\
\text { emergency department significantly } \\
\text { reduced patient waiting times and length } \\
\text { of stay, while improving satisfaction. This } \\
\text { was achieved over a two-year period with } \\
\text { a } 7 \% \text { growth in volume, without increasing } \\
\text { the size or resources of the department. }\end{array}$ & $\begin{array}{c}{ }^{*} \text { Not } \\
\text { classified }\end{array}$ \\
\hline
\end{tabular}

Chart 1 - Cont. 


\begin{tabular}{|c|c|c|c|c|c|}
\hline $\begin{array}{l}1^{\text {st }} \text { Author } \\
\text { Year } \\
\text { Place }\end{array}$ & Objective & $\begin{array}{l}\text { Type of study } \\
\text { Sample }\end{array}$ & Perspective & Main findings & $\begin{array}{l}\text { Level of } \\
\text { Evidence }\end{array}$ \\
\hline $\begin{array}{l}\text { Holden }^{(31)} \\
2015 \\
\text { Sweden }\end{array}$ & $\begin{array}{l}\text { To address how the perceptions } \\
\text { of health care workers varied } \\
\text { according to the contexts in three } \\
\text { Swedish hospitals. }\end{array}$ & $\begin{array}{l}\text { Mixed Method } \\
\mathrm{n}=236 \text { participants }\end{array}$ & & $\begin{array}{l}\text { The perceptions vary according to the } \\
\text { hospital context, to the complexity of the } \\
\text { sector, and to the professional role, with } \\
\text { nurses being the category with a more } \\
\text { favorable perception than physicians. }\end{array}$ & $\mathrm{VI}$ \\
\hline $\begin{array}{l}\text { Kanamori }^{(32)} \\
2015 \\
\text { Africa }\end{array}$ & $\begin{array}{l}\text { To assess how the } 5 \mathrm{~S} \text { management } \\
\text { method creates changes in the } \\
\text { workplace, process, and results } \\
\text { of the health services, and how it } \\
\text { can be applied in a low-resource } \\
\text { setting, based on data from a pilot } \\
\text { intervention of the } 5 \mathrm{~S} \text { program } \\
\text { implemented in a health system }\end{array}$ & $\begin{array}{l}\text { Qualitative } \\
\mathrm{n}=21 \text { participants }\end{array}$ & $\begin{array}{l}\text { Institutional } \\
\text { Professional }\end{array}$ & $\begin{array}{l}\text { The pilot intervention of the } 5 \mathrm{~S} \\
\text { management method generated changes } \\
\text { in the quality of the services and in the } \\
\text { attitude and behavior of the employees } \\
\text { and patients in a health facility with } \\
\text { few resources. }\end{array}$ & $\mathrm{VI}$ \\
\hline $\begin{array}{l}\text { Dávila(33) }^{(33)} \\
2015 \\
\text { Spain }\end{array}$ & $\begin{array}{l}\text { To evaluate cost reduction } \\
\text { and increased time devoted } \\
\text { to the patient, using the } \\
\text { Lean Healthcare methodology. }\end{array}$ & $\begin{array}{l}\text { Descriptive study } \\
\mathrm{n}=\text { Three rehabilitation } \\
\text { health services }\end{array}$ & $\begin{array}{l}\text { Institutional } \\
\text { Professional }\end{array}$ & $\begin{array}{l}\text { It was possible to standardize the } \\
\text { processes and eliminate waste, reducing } \\
\text { costs and increasing the value of the } \\
\text { patient. The costs with stored materials } \\
\text { decreased by } 43 \% \text {, the cost per patient } \\
\text { treated by } 19 \% \text {, and the time dedicated to } \\
\text { treating patients increased by } 7 \%\end{array}$ & $\mathrm{VI}$ \\
\hline $\begin{array}{l}\text { Drotz }^{(34)} \\
2014 \\
\text { Sweden }\end{array}$ & $\begin{array}{l}\text { To contribute to an understanding } \\
\text { of the new roles, responsibilities, } \\
\text { and job characteristics of } \\
\text { employees in Lean Healthcare }\end{array}$ & $\begin{array}{l}\text { Case study } \\
\mathrm{n}=24 \text { participants }\end{array}$ & Professional & $\begin{array}{l}\text { The implementation of Lean had a great } \\
\text { influence on the roles, responsibilities, and } \\
\text { characteristics of the employees' work, the } \\
\text { focus was shifted from the professionals } \\
\text { to the process of improvement } \\
\text { and teamwork }\end{array}$ & $\mathrm{VI}$ \\
\hline
\end{tabular}

Chart 1 - Cont. 


\begin{tabular}{|c|c|c|c|c|c|}
\hline $\begin{array}{l}1^{\text {st }} \text { Author } \\
\text { Year } \\
\text { Place }\end{array}$ & Objective & $\begin{array}{l}\text { Type of study } \\
\text { Sample }\end{array}$ & Perspective & Main findings & $\begin{array}{l}\text { Level of } \\
\text { Evidence }\end{array}$ \\
\hline $\begin{array}{l}\text { Ponanake }^{(35)} \\
2014 \\
\text { Thailand }\end{array}$ & $\begin{array}{l}\text { To study the trajectory relationships } \\
\text { between a Lean health system, } \\
\text { the Six Sigma practice and the } \\
\text { internal quality management of the } \\
\text { core competence of Thai private } \\
\text { hospitals as a health care center } \\
\text { of the Association of Southeast } \\
\text { Asian Nations }\end{array}$ & $\begin{array}{l}\text { Quantitative } \\
\mathrm{n}=312 \text { participants }\end{array}$ & Institutional & $\begin{array}{l}\text { The Lean health system and Six Sigma } \\
\text { practices indirectly influence, through } \\
\text { internal quality management, the core } \\
\text { competence of a hospital to be a health } \\
\text { care center. Six Sigma practices and } \\
\text { internal quality management directly } \\
\text { influence the same competence }\end{array}$ & $\mathrm{Vl}$ \\
\hline $\begin{array}{l}\text { Wood }^{(36)} \\
2014 \\
\text { Canada }\end{array}$ & $\begin{array}{l}\text { To examine three hospitals that } \\
\text { have implemented Lean in the } \\
\text { emergency department }\end{array}$ & $\begin{array}{l}\text { Longitudinal study } \\
\text { n=Three hospitals }\end{array}$ & $\begin{array}{l}\text { Institutional } \\
\text { Professional }\end{array}$ & $\begin{array}{l}\text { They concluded that, although the } \\
\text { presence of strong and persistent } \\
\text { leadership can have favorable results } \\
\text { in short-term performance, these } \\
\text { improvements are not sustainable. To } \\
\text { have a long-term impact, the professionals } \\
\text { need to engage all the stakeholders in the } \\
\text { health care system and create a culture } \\
\text { that is continuously focused on improving } \\
\text { the patient experience. }\end{array}$ & IV \\
\hline
\end{tabular}

\section{Chart 1 - Cont.}

Source: Research data, 2019.

*Study not included in the levels of evidence. 
"having a change agent in the unit" item, that is, most of the teams were highly qualified in the development, updating, and monitoring of the routines; however, $81 \%$ of the teams indicated that the unit did not have this "change agent". Maturity was also positively associated with care satisfaction and adherence to the national guidelines for improving quality of health care ${ }^{(20)}$.

Regarding the professional perspective, the studies presented findings related to job satisfaction ${ }^{(23,26)}$ and regarding the care provided ${ }^{(20)}$; medical adherence ${ }^{(21)}$ to Lean; workforce flexibility ${ }^{(27)}$; leadership of the team ${ }^{(27,36)}$; attitudes ${ }^{(31-32) ;}$ behavior ${ }^{(31)}$; commitment ${ }^{(32)}$; time devoted to assistance ${ }^{(33)}$, and the change of roles and responsibilities with the implementation of Lean $^{(34)}$.

One of the studies highlighted that medical adherence influences the results of Lean ${ }^{(21)}$, revealing that younger, less experienced physicians were more likely to be committed to the initiative; in addition, the training level and positive previous experience facilitated adherence to the method. Some factors of medical resistance were highlighted, such as longest professional experience, reorganization of the work process, and the threat in the power relationship ${ }^{(21)}$. As the challenge of adhering to Lean, the other health professionals face the different characteristics in the work process, autonomy in decision-making, and engagement of the team ${ }^{(34)}$.

The medical professional plays an important role for the culture of continuous improvement ${ }^{(21)}$; however, it is worth mentioning that the approach of the multidisciplinary team, together with the training of this philosophy, is fundamental for the achievement of results in the implementation and maintenance of Lean ${ }^{(13,39-40)}$.

Team training, process management, continuous improvement, and delegation of responsibilities have shown to be the pillars of this methodology, but it is necessary to involve the management to increase the motivation of the professionals and to avoid the exhaustion inherent to health work $^{(23)}$. Therefore, strong leadership and an engaged team are essential to build an organizational Lean culture ${ }^{(30,40)}$ where problems are seen as an opportunity for improvement, with the customer as main focus ${ }^{(41)}$.

As for the patient category, the aspects addressed were the following: satisfaction ${ }^{(25-26,30)}$, attitudes, and behavior ${ }^{(32)}$. This perspective was the least evaluated in the selected sample (22.2\%); however, it is important to consider the patient's needs in order to reduce costs and improve the care processes ${ }^{(42)}$, which reflects positively on quality and safety ${ }^{(2,6)}$.

\section{- CONCLUSION}

This study contributes to the need to establish a systematic assessment of Lean Healthcare after its implementation. The findings indicated that the most used category was institutional, with cost analysis and increased productivity being the most frequent results; followed by the professional, with job satisfaction and leadership as the most evaluated aspects and; finally, in the context of the patients, which was discussed as regards their satisfaction, attitudes, and behaviors. It should be highlighted that, in Lean, the value is defined by the patient and that this aspect in the results is still little explored.

This study provided an in-depth and integrated review on the theme; however, some limitations must be considered, such as the difference in the evaluation time after implementation; the various scenarios evaluated that make it impossible to compare institutions, and the predominance of the level of evidence $\mathrm{VI}$, which should be considered in prospective studies. Therefore, it reinforces the need to establish, for the management, a systematic method of monitoring the results achieved in the implementation phase of Lean Healthcare.

The importance of expanding and continuing investigations in this field is highlighted, with well-defined and robust methods, in order to better understand the success factors and barriers to their implementation, in addition to their long-term impact for the institution, the professional, and the patient, as well as the maturity of the philosophy.

\section{REFERENCES}

1. Radnor ZJ, Holweg M, Waring J. Lean in healthcare: the unfilled promise? Soc Sci Med. 2012;74(3):364-71. doi: https://doi.org/10.1016/j.socscimed. 2011.02.011

2. Costa LBM, Godinho Filho M. Lean healthcare: review, classification and analysis of literature. Prod Plan Control. 2016;27(10):823-36. doi: https://doi.org/10.10 80/09537287.2016.1143131

3. D'Andreamatteo A, lanni L, Lega F, Sargiacomo M. Lean in healthcare: a comprehensive review. Health Policy. 2015;119(9):1197-209 doi: https://doi. org/10.1016/j.healthpol.2015.02.002

4. Womack JP. Going lean in healthcare. Cambridge: Institute for Healthcare Improvement; 2005. (Innovation Series)

5. WomackJP, Jones DT. BeyondToyota: how to root out waste and pursue perfection. Harvard Bus Rev. 1996 [cited 2019 Aug 15];74(5):140-58. Available from: https://hbr.org/1996/09/how-to-root-out-waste-and-pursue-perfection

6. Hussain M, Malik M, Al Neyadi HS. AHP framework to assist lean deployment in Abu Dhabi public healthcare delivery system. Bus Process Manag J. 2016;22(3):546-65. doi: https://doi.org/10.1108/BPMJ-08-2014-0074 
7. Pazeti M, Calache L. Application of Lean Six Sigma Concepts to Medicine Dispensation of Public Health Centers. Advances in Human Factors and Ergonomics in Healthcare. 2017;482:119-27. doi: https://doi.org/10.1007/ 978-3-319-41652-6_12

8. Fernández Aranda MI. Aplicación del método Lean Healthcare en un servicio de ginecología y obstetrícia. Metas Enferm. 2016 [citado 2019 jul 15];19(1):21-6. Disponíble en: https://www.enfermeria21.com/revistas/metas/articulo/80858/ aplicacion-del-metodo-lean-healthcare-en-un-servicio-de-ginecologia-yobstetricia/

9. Henrique DB, Rentes AR, Godinho Filho M, Esposto KF. A new value stream mapping approach for healthcare environments. Prod Plan Control. 2015;27(1):24-48. doi: https://doi.org/10.1080/09537287.2015.1051159

10. Al-Balushi MM, Al-Mandhari Z. Implementing Lean Management Techniques at a radiation oncology department. Int J Health Plann Manage. 2017 Apr;32(2):133-46. doi: https://doi.org/10.1002/hpm.2334

11. Hassanain M, Zamakhshary M, Farhat G, Al-Badr A. Use of Lean methodology to improve operating room efficiency in hospitals across the Kingdom of Saudi Arabia. Int J Health Plann Manage. 2017 Apr;32(2):133-46. doi: https://doi. org/10.1002/hpm.2334

12. Leite SC, Ferreira SF, Calixtro LG, Carvalho GM, Sarantopoulos A. Enteral diet therapy: use of the Lean Healthcare philosophy in process improvement. Rev Bras Enferm. 2019;72(Suppl 1):235-22. doi: https://doi. org/10.1590/0034-7167-2017-0746

13. Zeferino EBB, Sarantopoulos A, Spagnol GS, Min LL; Freitas, MIP. Value Flow Map: application and results in the disinfection center. Rev Bras Enferm. 2019;72(1):140-6. doi: https://doi.org/10.1590/0034-7167-2018-0517

14. Amaratunga T, Dobranowski J. Systematic review of the application of Lean and Six Sigma quality improvement methodologies in radiology. J Am Coll Radiol. 2016;13(9):1088-95.e7. doi: https://doi.org/10.1016/j.jacr.2016.02.033

15. Hallam CRA, Contreras C. Lean healthcare: scale, scope and sustainability. Int J Health Care Qual Assur. 2018 Aug;31(7):684-96. doi: https://doi.org/10.1108/ IJHCQA-02-2017-0023

16. Lawal AK, Rotter T, Kinsman L, Sari N, Harrison L, Jeffery C, et al. Lean management in health care: definition, concepts, methodology and effects reported (systematic review protocol). Syst Rev. 2014;3 103. doi: https://doi. org/10.1186/2046-4053-3-103

17. Liberati A, Altman DG, Tetzlaff J, Mulrow C, Gøtzsche PC, loannidis JP, et al. The PRISMA statement for reporting systematic reviews and meta-analyses of studies that evaluate healthcare interventions: explanation and elaboration. PLoS Med. 2009 Jul 21;6(7):e1000100. doi: https://doi.org/10.1371/journal. pmed. 1000100

18. Whittemore R, Knafl K. The integrative review: updated methodology. J Adv Nur. 2005;52(5):543-53. doi: https://doi.org/10.1111/j.1365-2648.2005.03621.x

19. Stillwell SB, Fineout-Overholt E, Melnyk BM, Williamson KM. Searching for the evidence: strategies to help you conduct a successful search. Am J Nurs. 2010;110(1):41-7.doi:https://doi.org/10.1097/01.NAJ.0000372071.24134.7e

20. Kaltenbrunner M, Mathiassen SE, Bengtsson L, Engström M. Lean maturity and quality in primary care. J Health Organ Manage. 2019;33(2):141-54. doi: https://doi.org/10.1108/JHOM-04-2018-0118

21. Fournier PL, Jobin MH. Medical commitment to Lean: an inductive model development. Leadersh Health Serv. 2018;31(3):326-42. doi: https://doi. org/10.1108/LHS-02-2018-0015
22. Gupta SH, Kapil S, Sharma M. Improvement of laboratory turnaround time using lean methodology. Int J Health Care Qual Assur. 2018;31(4):295-308. doi: https://doi.org/10.1108/JJHCQA-08-2016-011

23. Boronat F, Budia A, Broseta E, Ruiz-Cerdá UL, Vivas-Consuelo D. Application of Lean Healthcare methodology in a urology department of a tertiary hospital as a tool for improving efficiency. Actas Urol Esp. 2018;42(1):42-8. doi: https://doi. org/10.1016/j.acuro.2017.03.009

24. Costa LBM, Godinho Filho M, Rentes AF, Bertani TM, Mardegan R. Lean healthcare in developing countries: evidence from Brazilian hospitals. Int J Health Plann Manage. 2017;32: E99-E120. doi: https://doi.org/10.1002/hpm.2331

25. Poksinska BB, Fialkowska-Filipek M, Engström J. Does Lean healthcare improve patient satisfaction? A mixed-method investigation into primary care. BMJ Qual Saf. 2017;26:95-103. doi: https://doi.org/10.1136/bmjqs-2015-004290

26. Mutingi M, Isack HD, Musiyarira H, Mbohwa C. The impact of lean in medical laboratory industry: empirical studies in Namibia. In: World Congress on Engineering and Computer Science, WCECS 2017; Lecture Notes in Eng Comput Sci. 2017;11:965-9

27. Van Rossum L, Aij KH, Simons FE, der Eng NV, ten Have WD. Lean healthcare from a change management perspective: the role of leadership and workforce flexibility in an operating theatre. J Health Organ Manag. 2016;30(3):475-43. doi: https://doi.org/10.1108/JHOM-06-2014-0090

28. Trzeciak S, Mercincavage M, Angelini C, Cogliano W, Damuth E, Roberts BW, et al. Lean Six Sigma to reduce intensive care unit length of stay and costs in prolonged mechanical ventilation. J Healthc Qual. 2018 Jan/Feb;40(1):36-43. doi: https://doi.org/10.1097/JHQ.0000000000000075

29. Eiro NY, Torres-Junior AS. Comparative study: TQ and Lean Production ownership models in health services. Rev Latino-Am Enfermagem. 2015 Sept./ Oct;23(5):846-54. doi: https://doi.org/10.1590/0104-1169.0151.2605

30. Kane M, Chui K, Rimicci J, Callagy P, Hereford J, Shen S, et al. Lean Manufacturing improves emergency department throughput and patient satisfaction. J Nurs Adm. 2015;45(9):429-34. doi: https://doi.org/10.1097/ NNA.0000000000000228

31. Holden RJ, Eriksson A, Andreasson J, Williamsson A, Dellve L. Healthcare workers' perceptions of Lean: a context-sensitive, mixed methods study in three Swedish hospitals. Appl Ergon. 2015;47:181-92. doi: https://doi.org/10.1016/j. aperg0.2014.09.008

32. Kanamori SH, Sow S, Castro MC, Matsuno R, Tsuru A, Jimba M. Implementation of $5 \mathrm{~S}$ management method for lean healthcare at a health center in Senegal: a qualitative study of staff perception. Glob Health Action. 2015;8:27256. doi: https://doi.org/10.3402/gha.v8.27256

33. Dávila SP, González JT. Mejora de la eficiencia de un servicio de rehabilitación mediante metodología Lean Healthcare. Rev Calid Asist. 2015;30(4):162-5. doi: https://doi.org/10.1016/j.cali.2015.03.002

34. Drotz E, Poksinska B. Lean in healthcare from employees' perspectives. J Health Organ Manag. 2014;28(2):177-95. doi: https://doi.org/10.1108/ JHOM-03-2013-0066

35. Ponanake P, Limnararat S, Pithuncharurnlap M, Sangmanee W. Path analysis of the core competency of Thai private hospitals in the ASEAN economic community. Res J Bus Manag. 2014;8(3):157-72. doi: https://doi.org/10.3923/ rjbm.2014.157.172

36. Wood D. A Prescription for Lean Healthcare. Healthc Q. 2014;17(2):24-8. doi: https://doi.org/10.12927/hcq.2014.23881 
37. Antierens A, Beeckman D, Verhaeghe S, Myny D, Van Hecke A. How much of Toyota's philosophy is embedded in health care at the organisational level? a review. J Nurs Manag. 2018 May;26(4):348-57.doi: https://doi.org/10.1111/ jonm. 12555

38. Hasle P, Nielsen AP, Edwards K. Application of lean manufacturing in hospitals - the need to consider maturity, complexity, and the value concept. Human Factors Ergon Manuf Serv Ind. 2016;26(4):430-42. doi: https://doi. org/10.1002/hfm.20668

39. Honda AC, Bernardo VZ, Gerolamo MC, Davis MM. How Lean Six Sigma principles improve hospital performance. Qual Manag J. 2018;25(2):70-82 doi: https://doi.org/10.1080/10686967.2018.1436349

40. Henrique DB, Godinho Filho M. A systematic literature review of empirical research in Lean and Six Sigma in healthcare. Total Qual Manag. 2020;31(4):42949 doi: https://doi.org/10.1080/14783363.2018.1429259
41. Romeu-Silva SN, Spagnol GS, Li LM . Lean Healthcare modelo de gestão para projeto piloto no Ambulatório de Neurologia/AVC. Rev Saberes Univers. 2016 [citado 2019 jul 15];1(2):3-13. Disponível em: https://econtents.bc.unicamp. br/inpec/index.php/saberes/article/view/6949/4344

42. MinLL,SharonJ.Leanthinking turns'timeis brain'into reality. Arq.Neuro-Psiquiatr. 2015;73(6):526-30. doi: https://doi.org/10.1590/0004-282X20150047

\section{Acknowledgment:}

Coordination for the Improvement of Higher Level Personnel (Coordenação de Aperfeiçoamento de Pessoal de Nivel Superior, (APES) - Brazil - Finance Code 88882.434708/2019-01.

\section{- Corresponding author:}

Hellen Maria de Lima Graf Fernandes

Email: hellenmlima@gmail.com

\section{Editor-in-chief:}

Maria da Graça Oliveira Crossetti 